UDC 532.783

\title{
NMR STUDY OF THE OXIDATIVE CHLOROPHOSPHORYLATION OF STYRENE-BUTADIENE RUBBER
}

\author{
N.A.Efendiyeva, A.M.Maharramov, A.A.Azizov, A.Y.Melikova, \\ I.A.Bunyad-zadeh, R.M.Alosmanov
}

\author{
Baku State University \\ i_buniatzade@mail.ru
}

Received 12.03.2019

\begin{abstract}
The reaction of oxidative chlorophosphorylation of styrene-butadiene rubber was studied by ${ }^{1} \mathrm{H},{ }^{13} \mathrm{C}$, and
${ }^{31} \mathrm{P}$ NMR method. Investigations of functionalized styrene-butadiene rubber were carried out using low phosphorus containing samples selected from reaction medium at regular intervals. The obtained results have been discussed in detail, and make it possible to interpret the mechanism of the reaction and the structure of the polymer obtained.
\end{abstract}

Keywords: oxidative chlorophosphorylation, styrene-butadiene rubber, NMR measurements.

https://doi.org/10.32737/0005-2531-2019-3-20-24

\section{Introduction}

Oxidative chlorophosphorylation is one way to synthesize phosphorus-containing organic compounds and polymers [1-11]. In spite of the fact that publications addressing the synthesis of phosphorus-containing compounds have presented extensive information on different low-molecular-weight compounds and have studied the mechanism of the reaction and the chemical structure of the products obtained [16] studies of polymers of the polyolefin type (polyethylene, polypropylene, polyvinyl acetate etc.) and contain information relating mainly to the properties of the polymers obtained [7-11]. Our team for the first time have been investigated the oxidative chlorophosphorylation of diene polymers on example of butadiene rubber (BR) $[12,13]$. It was confirmed that during the oxidative chlorophosphorylation of $\mathrm{BR}$ by the action of $\mathrm{PCl}_{3}$ in the presence of oxygen, functionally active groups with $\mathrm{P}-\mathrm{Cl}$ bonds are introduced into the polymer matrix, as in the case of polyolefin polymers. But unlike of polyolefines during the modification reaction of the BR occurs cross-linking process between macromolecular chains. On the other hand it is known that the oxidative chlorophosphorylation of polystyrene proceeds mainly with the destruction of the polymer backbone [2]. So it would be interesting to study the oxidative chlorophosphorylation of styrene-butadiene rubber (SBR) which is the copolymer of butadiene and styrene.

In this work we have studied the oxidative chlorophosphorylation of styrene-butadiene rubber using NMR spectroscopy. It should be noted that these researches have also a practical value. So, preparation of phosphorus-containing polymers on the basis of one of the most widely produced elastomers - SBR - seems to be very promising.

\section{Experimental part}

\section{Materials and their purification}

SBR was purchased from Voronezh Synthetic Rubber Manufactory (Russia). Its macromolecular structure is shown in Figure 1.<smiles>C=CC(C)CC</smiles>

1,2-butadiene

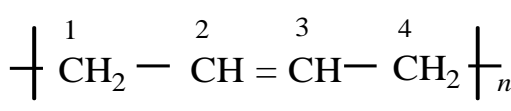

1,4-butadiene<smiles>CC(C)c1ccccc1</smiles>

styrene

Fig.1. Macromolecular structures of the SBR 
To prepare the initial SBR for the experiments, the latter was dissolved in $\mathrm{CCl}_{4}$ with subsequent precipitation in $\mathrm{CH}_{3} \mathrm{OH}$ for removing the different kinds of impurity. $\mathrm{CCl}_{4}$ and $\mathrm{PCl}_{3}$ were purified by distillation, and oxygen was dried by passing it through concentrated $\mathrm{H}_{2} \mathrm{SO}_{4}$.

\section{Methods}

Preparation of samples (oxidative chlorophosphorylation reaction of $\mathrm{SBR}$ )

A $2 \%$ solution of $\mathrm{SBR}$ in $\mathrm{CCl}_{4}$ was prepared. After that $\mathrm{PCl}_{3}$ was added to the reaction mixture in weight ratio of 1:5 (SBR: $\left.\mathrm{PCl}_{3}\right)$ and the reaction system was purged with oxygen at a rate $7 \mathrm{~L} / \mathrm{h}$. Reaction started at $22 \pm 2^{0} \mathrm{C}$ and due to exothermic character the temperature increased up to $55-60^{\circ} \mathrm{C}$. After $1 \mathrm{~h}$ polymer as a result of crosslinking reaction precipitated, i.e. occurs heterogenization in the reaction medium. The total duration of reaction $-8 \mathrm{~h}$. Low phosphorus containing samples were sequentially selected from reaction medium during the oxidative chlorophosphorylation(ChP) of SBR at regular intervals (25 and $50 \mathrm{~min}$ ) that were identified as ChPSBR-1 and ChP-SBR-2, respectively.

\section{Nuclear Magnetic Resonance spectros- copy analysis}

The samples were characterized by $\mathrm{Nu}-$ clear Magnetic Resonance (NMR) spectroscopy using a Bruker AV300 spectrometer $\left({ }^{1} \mathrm{H} 300\right.$ $\mathrm{MHz},{ }^{13} \mathrm{C} 75 \mathrm{MHz}$ and $\left.{ }^{31} \mathrm{P} 12.4 \mathrm{MHz}\right)$. The spectrometer was connected to an HP computer. The ${ }^{1} \mathrm{H}$ NMR spectrum was obtained with pulses of $7.3 \mu$ s width $\left(20{ }^{\circ} \mathrm{C}\right)$, with a pulse delay of $3 \mathrm{~s} ; 2 \%$ (by mass) solutions of the reaction products in $\mathrm{CCl}_{4}$ were used. The ${ }^{13} \mathrm{C} \mathrm{NMR}$ spectrum was taken with ${ }^{1} \mathrm{H}\left({ }^{13} \mathrm{C}\right)$ suppression, with a pulse width of $9 \mu$ s $\left(20^{\circ} \mathrm{C}\right)$, a pulse delay of $1 \mathrm{~s}$, and $\mathrm{CCl}_{4}$ as the solvent (external reference $\mathrm{D}_{2} \mathrm{O}$ ). The chemical shift was calculated on the basis of the external $\left(\mathrm{CH}_{3}\right)_{4} \mathrm{Si} \mathrm{DEPT} \mathrm{sig-}$ nal obtained using the standard DEPT program (Bruker).

\section{Results and discussion}

The NMR investigations of modified SBR was preceded by ${ }^{1} \mathrm{H},{ }^{13} \mathrm{C}$ NMR analysis of the structure of initial polymer.

The ${ }^{1} \mathrm{H}$ NMR spectra of SBR and of ChP-SBR samples are shown in Figure 2.

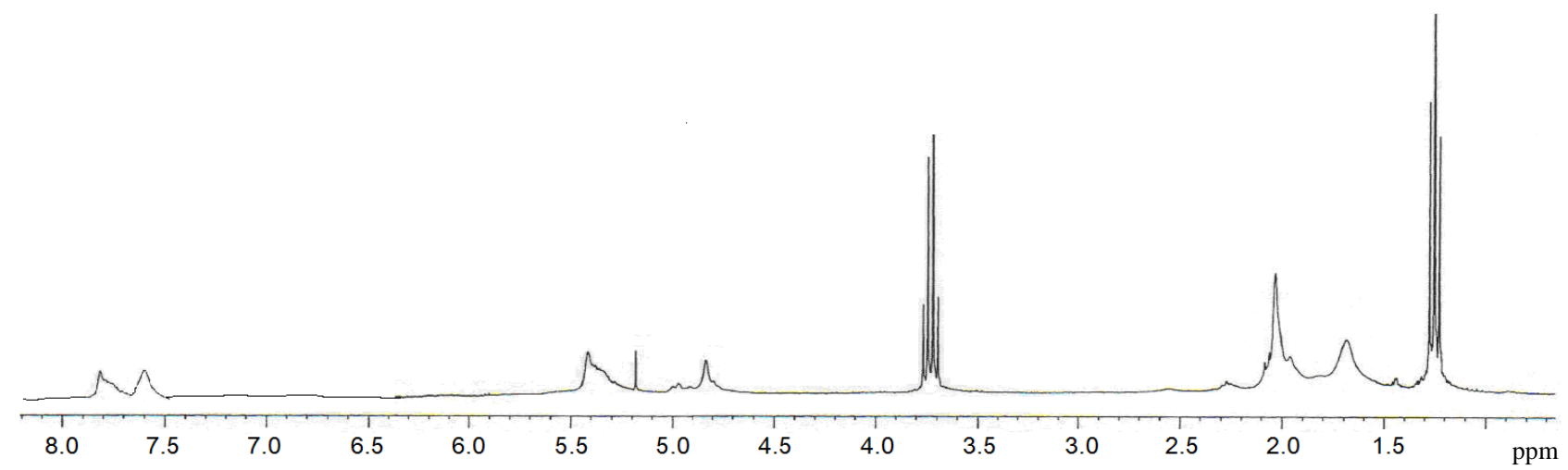

Fig. $2(a) .{ }^{1} \mathrm{H}$ spectrum of SBR.

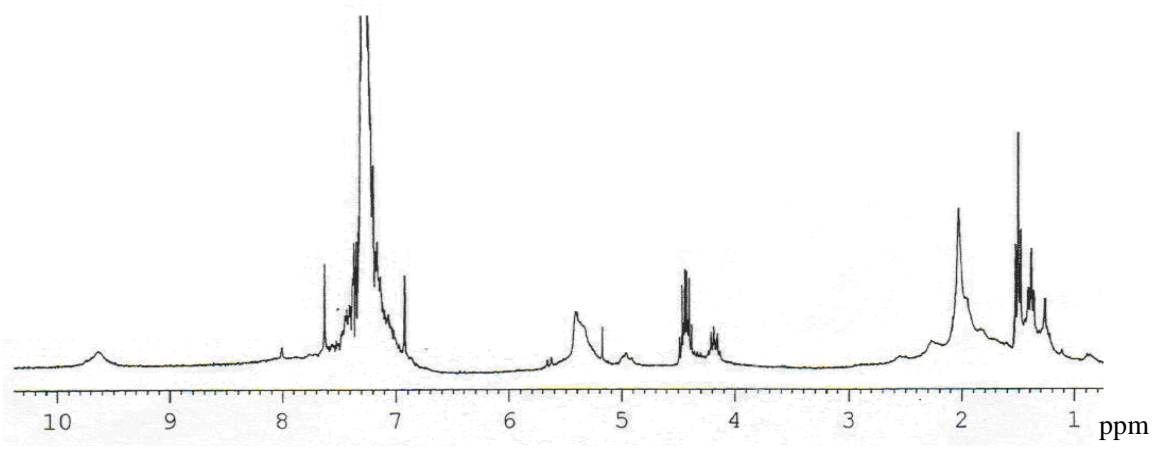

Fig. $2(b) .{ }^{1} \mathrm{H}$ spectrum of ChP-SBR-1. 


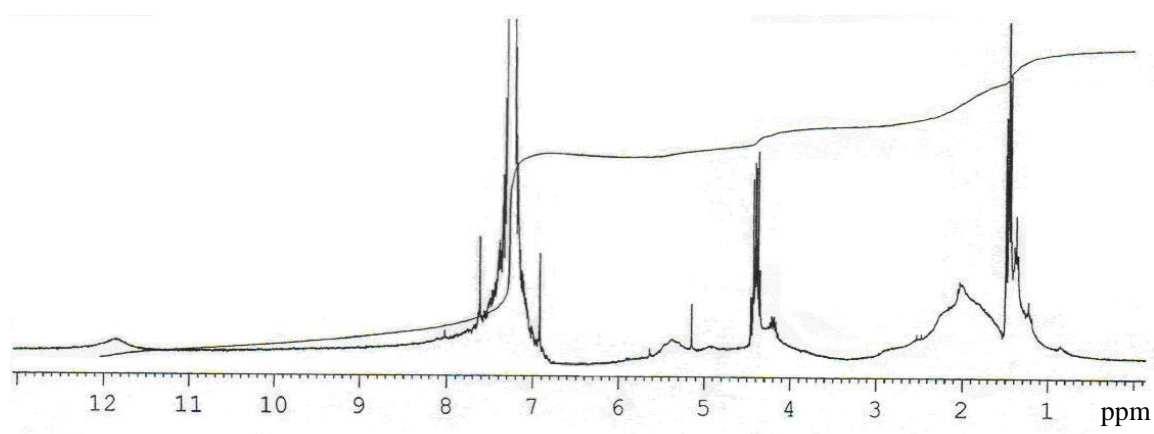

Fig. 2 (c). ${ }^{1} \mathrm{H}$ spectrum of ChP-SBR-2.

As seen from Figure $2(a)$, in initial SBR signals corresponding to aliphatic protons $(\sim 2$ $\mathrm{ppm})$ as well as to aromatic protons $(\sim 7.5 \mathrm{ppm})$ can be found. The multiple signals in the 4.85.5 region relate to unsaturated functionalities $\left(-\mathrm{CH}=\mathrm{CH}_{2},-\mathrm{CH}=\mathrm{CH}-\right)$. In comparison with initial polymer the noticeable changes can be observed in ${ }^{1} \mathrm{H}$ spectrums of ChP-SBR-1 and ChP-SBR-2 samples in 4.0-4.8 and 6.8-8 ppm region. The appearance of new signals in ChPSBR-1 and ChP-SBR-2 samples can be referred to $>\mathrm{CH}-\mathrm{Cl}(\sim 4.1$ and $\sim 4.5 \mathrm{ppm})$ and $>\mathrm{CH}-\mathrm{O}$ $(\sim 4.8 \mathrm{ppm})$ groups. It should be noted that the modification of vinyl bonds in the butadiene part of the polymer is carried out with high speed. This can be explained by absence of any steric hindrance for the addition reaction. The modified macromolecule conformation contributes to the screening of styrene fragments and makes it more stable for external influence. Thus, some broadening of absorption bands in 6.8-8 ppm region and new signals in $4.0-4.8$ ppm suggested the primary modification in the butadiene part of the polymer.

In Figure $3 \mathrm{NMR}{ }^{13} \mathrm{C}$ spectrum of initial (2a) and ChP-SBR (2b) have been presented.

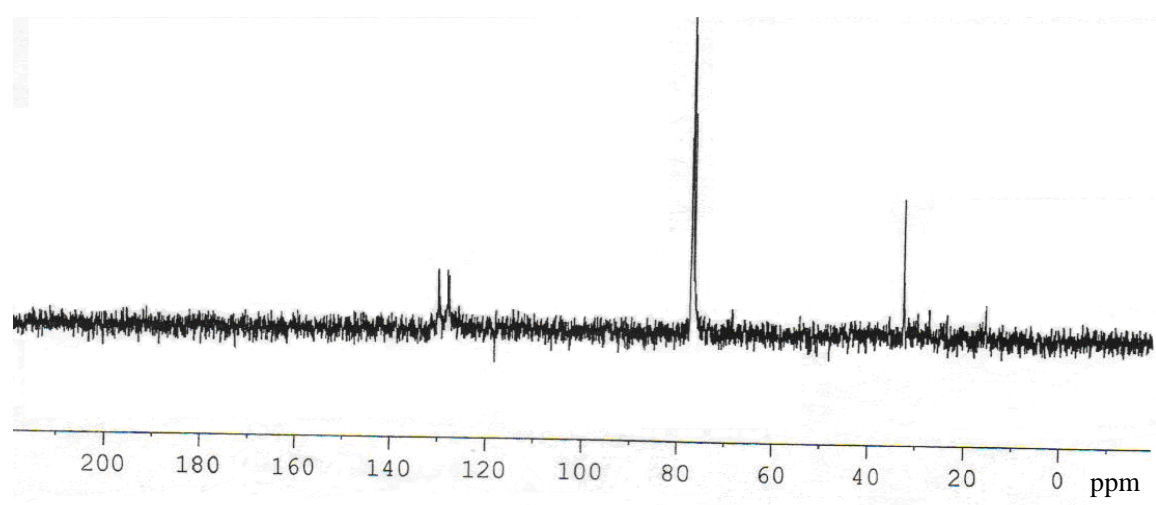

Fig. $3(a) .{ }^{13} \mathrm{C}$-spectrum of SBR

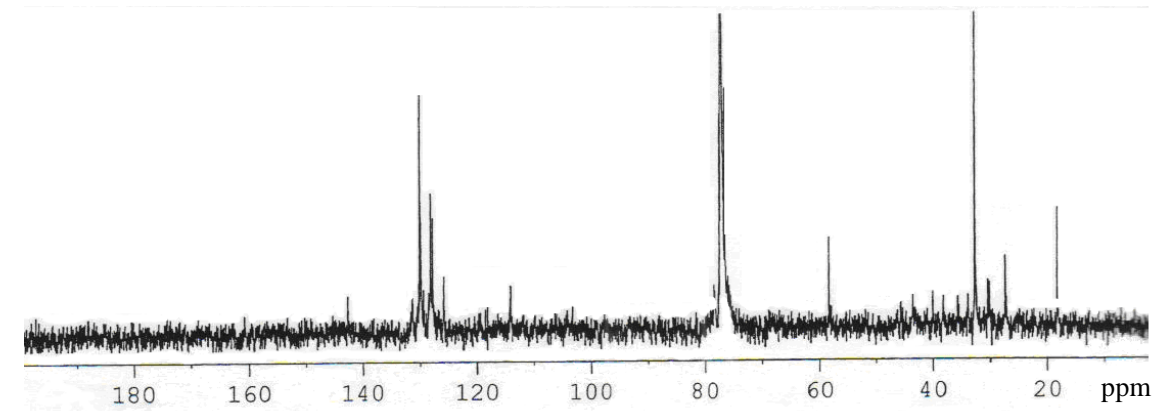

Fig. $3(b) .{ }^{13} \mathrm{C}$-spectrum of ChP-SBR-1. 
As seen from Figure $3(a, b)$, some signal intensity decrease and some broadening of the band are observed not only in aliphatic part of spectrums. The 25-45 ppm region corresponding to the $\mathrm{C} 1$ and $\mathrm{C} 2$ carbons in vinyl or styrene groups and the $\mathrm{C} 1$ and $\mathrm{C} 4$ carbons in the cis and trans units. The 125-132 ppm region corresponding to the $\mathrm{C} 3$ and $\mathrm{C} 4$ carbons in vinyl units; $\mathrm{C} 2$ and $\mathrm{C} 3$ in cis and trans units; $\mathrm{C} 3, \mathrm{C} 8$ in styrene units, that correlated with data presented in [14]. Signal at $78-80$ ppm refers to the solvent. The broadening observed in the NMR ${ }^{13} \mathrm{C}$ spectrum indicates that the molecular mobility of the polymer chains is reduced after chlorophosphorylation. This is mainly due to the fact that the resonance line width is related to the segmental polymer motion. If the molecule is free to move in any direction, then the spectrum line width is narrow. On the other hand, if the motion is restricted, then the line width increases. In terms of rubber chlorohposphorylation processes, it seems to be consistent with the formation of extra cross-links restricting the motion of molecules, since the chains lose their ability to move as individual polymer chains. The nature of spectrum confirmed that in double bonds region synthesized compounds are more flexible and homogeneous [15]. The ${ }^{13} \mathrm{C}-\mathrm{NMR}$ spectrum of Ch SBR (Figure $3 b$ ), along with signals related to styrene and butadiene units, showed new characteristic signals assigned to phosphonyldichloride (>CH-POCl $2,38-42$ ppm), phosphoryldichloride $\left(>\mathrm{CH}-\mathrm{O}-\mathrm{POCl}_{2}, \sim 78 \mathrm{ppm}\right)$ and $>\mathrm{CHCl}$ groups (57-60 ppm).

The ${ }^{31} \mathrm{P}$ NMR spectrum of Ch-SBR (Figure 4) confirmed the presence of $>\mathrm{CH}-\mathrm{O}-$ $\mathrm{POCl}_{2}$ group (7.5-7.8 ppm) in sample. Thus, the analysis of the spectra, no changes were found in the styrene units of the ChP-SBR, which can be interpreted as follows. At the initial stage of oxidative chlorophosphorylation reaction, due to sterically more accessibility and high percentage the butadiene units can be easily subject to modification. As a result, the conformation will be changed and the macromolecules take a relatively curved shape. This contributes to the preservation of the styrene unit in an unmodified form.

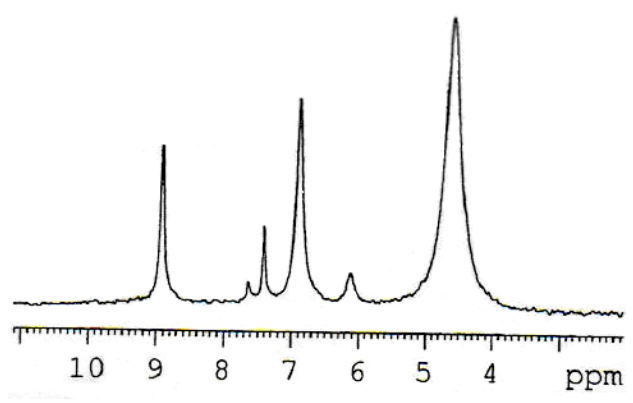

Fig. 4. ${ }^{13} \mathrm{P}$-spectrum of ChP-SBR-1

\section{Conclusions}

ChP-SBR-1 and ChP-SBR-2 samples of chlorophosphorylated SBR have been investigated using ${ }^{1} \mathrm{H},{ }^{13} \mathrm{C},{ }^{31} \mathrm{P}-\mathrm{NMR}$ measurements. It has been established that despite of the presence of styrene units in macromolecules of SBR chemical modification of the polymer proceeds similarly to butadiene rubber. This is explained by the fact that the reaction begins in the butadiene unit of the SBR and is accompanied by conformational changes in the macromolecules.

\section{References}

1. Zinov'ev Yu.M., Soborovskii L.Z. Reactions and Methods of Investigation of Organic Compounds. Ed. by B.A.Kazanskiy. M.: Khimiya, 1970. P. 6-38.

2. Levin Ya.A.,Vorkunova E.I. Homolytic Chemistry of Phosphorus. M.: Nauka, 1978. 320 p.

3. Pat. 2043358 RF. Method for production of phosphoenol pyruvate. Gurevich I.E., Dogadina A.V., Ionin B.I, Krivchun M.N. 1995.

4. Grigoriev Ye.V., Saginova L.G. Reactions of 3,5diaryl-1,2-oxathiolane-2-oxides with phosphorus trichloride. Vestn. Moskovskogo Univ. Ser. 2. Khim. 2006. V. 47. No 3. P. 223. 
5. Shvedova Yu.I., Shilov S.A., Sendurev M.V., Dogadina A.V., Ionin B.L., Petrov B.I. Homolytic interaction of phosphorus trihalides with eninic hydrocarbons. Russian J. General chem. 1988. V. 58. No 6. P. 1224-1235.

6. Mayo F.R., Durham L.J., Griggs K.S. The reaction of alkanes with phosphorus trichloride and oxygen. J. Am. Chem. Soc. 1963. V. 85. No 20. P. 3156-3164.

7. Fedtke M., Sperhacke R. Oxydative Chlorophosphonylization of Ethylene-Vinyl Acetate Copolymers. Plaste und Kautschuk. 1977. V. 24. No 1. P. 24-26.

8. Fedtke M. Topical Problems of Stabilizing Polyolefins. Plaste und Kautschuk. 1977. V. 24. No 2. P. 92-94.

9. Korshak V.V. Advances in the Field of the Synthesis of Heteroorganic Polymers. M.: Nauka. 1998. 320 p.

10. Khardin A.P., Tuzikov O.I., Bondarenko S.N. Phosphorylation of Carbochain Polymers. Russian chemical reviews. 1983. V. 52. No 7. P. 662.

11. Trifonov S.A., Sosnov E.A., Maligin A.A. The influence of the chemical modification with phos-
phorus(III) chloride of the surface of polyethylene on its thermo-oxidative resistance. VINITI Database RAS. 2002. 374-V.

12. Alosmanov R.M., Azizov A.A., Magerramov A.M. NMR spectroscopic study of phosphorus-containing polymer sorbent. Russian J. General chem. 2011. V. 81. P. 1477-1479.

13. Pat. I 2005 0142. Az.R. Method for preparation of sorbents containing phosphoric acid fragments. Azizov A. A., Rahimov R.A., Alosmanov R.M., Akperov O.H. 2005.

14. Munteanua B. S., Vasile C. Spectral and thermal characterization of styrene-butadiene copolymers with different architectures. Journal of Optoelectronics and Advanced Materials. 2005. V. 7. No 6. P. 3135-314.

15. Arantes T.M., Leao K.V., Tavares M.B., Ferreira A.G., Longo E., Emerson R., Camargo E.R. NMR study of styrene-butadiene rubber (SBR) and $\mathrm{TiO}_{2}$ nanocomposites. Polymer Testing. 2009. V. 28. P. 490-494.

\section{BUTADİEN-STIROL KAUÇUKUNUN OKSIDLOŞMO XLORFOSFORLAŞMA NMR METODU İLa TəDQİQI}

\section{N.A.Әfəndiyeva, A.M.Məhərrəmov, A.ə.Ozizov, A.Y.Məlikova, İ.A.Bünyadzadə, R.M.Alosmanov}

Butadien-stirol kauçukunun oksidləşmə xlorfosforlaşma reaksiyası ${ }^{1} \mathrm{H},{ }^{13} \mathrm{C}$, və ${ }^{31} \mathrm{P}$ NMR metodu ilə tədqiq olunmuşdur. Tədqiqatlar üçün reaksiya mühitindən müəyyən zaman fasilələri ilə götürülmüş və tərkibində az miqdarda fosfor olan funksiyalaşdırılmış butadien-stirol kauçuku nümunələrindən istifadə edilmişdir. Alınmış nəticələr ətraflı analiz olunmuşdur. Nəticə reaksiyanın mexanizminin interpretasiyası alınmış polimerin quruluşu müəyyənləşdirilmişdir.

Açar sözlər: oksidloşmə xlorfosforlaşma, butadien-stirol kauçuku, NMR metodu ilə tədqiqi.

\section{ИССЛЕДОВАНИЕ МЕТОДОМ ЯМР ОКИСЛИТЕЛЬНОГО ХЛОРФОСФОРИЛИРОВАНИЯ БУТАДИЕН-СТИРОЛЬНОГО КАУЧУКА}

\section{Н.А.Эфендиева, А.М.Магеррамов, А.А.Азизов, А.Я.Меликова, И.А.Буният-заде, Р.М.Алосманов}

Методом ${ }^{1} \mathrm{H},{ }^{13} \mathrm{C}$, и ${ }^{31} \mathrm{P}$ ЯМР исследовано окислительное хлорфосфорилирования бутадиен-стирольного каучука. Исследование проводилось с использованием образцов функционализированного бутадиен-стирольного каучука с низким содержанием фосфора, которые отбирались из реакционной среды через определенные промежутки времени. Полученные результаты детально проанализированы, что позволило интерпретировать механизм реакции и структуру получения полимера.

Ключевые слова: окислительное хлорфосфорилирование, бутадиен-стирольный каучук, метод ЯМР. 